\title{
The Improvement of Production Process Impact in Furniture Industry Toward Circular Economy
}

\author{
Purnawan Adi Wicaksono* Choirunisa Ahmad Kadafi \\ Industrial Engineering Department, Diponegoro University, Semarang 50275, Indonesia
}

\begin{abstract}
Furniture industry is the industry that processes raw or semifinished material from wood, rattan, or other natural material, into products with higher value added and benefit. Because of a rise in consumer demand each year, the furniture industries should have much attention. High consumer demand may cause production process-related problems that damage the environment. Such environmental damage may be caused by waste, raw materials, or production process. High consumer demand in furniture industry brings negative impacts not only to the environment but also to the society. Social impact assessment is needed to evaluate how a product or a process influences workers, consumers, citizen, and value chain. This study uses life cycle assessment method with the help of SimaPro software to determine the environmental impact, and social-life cycle assessment to determine the social impact. The largest contributor to environmental impact is the use of acrylic varnish. Substitution acrylic varnish with woodstain-water based aims to lead to a circular economy by reducing adverse impacts on the environment. The replacement of acrylic varnish with woodstain water based reduces the environmental impact score by $24.8 \%$. Social impacts score on the workers and local community stakeholder are categorized as poor.
\end{abstract}

\section{Introduction}

Circular Economy (CE) is an alternative industrial model where by taking a holistic and systemic approach, industrial processes are not seen as an inevitable cause of exploitation of natural resources, environmental pollution, and waste generation, but rather as a means to contribute to sustainable development [1]. In the context of sustainable global discussions, environmental damage is the impact of an industrial where irreversible environmental damage such as the release of greenhouse gases and the massive exploitation of non- renewable natural resources must be significantly reduced. In addition, the use of natural resources or materials that are not optimal will produce production waste, which will cause loss of economic value inherent to the material and the presence of improper disposal will cause environmental degradation and adverse impacts on the health of the local community [2].

Furniture industry is an industry that processes raw materials or semi-finished materials from wood, rattan, and other natural raw materials into finished products with higher value

* Corresponding author: purnawan@ft.undip.ac.id 
added and benefits. The production process in furniture industry produces a furniture product and several non-product output (NPO) or waste [3]. The produced waste affects the resources, environmental damage and the society. The amount of waste produced by the furniture industry is approximately $40 \%$ of the raw materials [4], with at least $7 \%$ and at most $50 \%$ of those raw material waste comes from wood materials that will become residue [5]. A part from waste, environmental impacts can also be caused by raw materials and production processes [6]. Therefore, choosing eco-friendly raw materials is considered an important factor in reducing environmental impact [7]. Various raw materials used in furniture production contain chemicals which significantly contribute in environmental impacts through its composition [8]. Transparent wood coatings protect wood from environmental effects such as humidity, mechanical and chemical damage, but this wood coating contains a kind of liquid consisting of chemical solvents or water that has the potential to emit volatile organic compounds (VOC). Moreover, the main raw materials in the furniture production process is glue or adhesives. Glue is an important material used to stick the wood surfaces together, but it brings harmful impact for both humans and the environment [9]. Besides bringing negative impact to the environment, the high production demand in furniture industry also impacts the society. Assessments on social impact are needed to evaluate how a product or process affects workers, costumers, society and the value chain [10]. Among the social impacts related to workers is the decline in worker welfare, which is caused by high production activities. The furniture industry is also facing a lot of obstacle in expanding the operation and in overcome the social impact such as the discrimination of workers, heritage and inheritance conservation, and fair wage demand from the workers. Thus, the furniture industry is required to reduce the negative impact on the environment and the social impact on the environment and the society of its activities. The purposes of the study are to assess the environment impact and the social impact in practicing the LCA and SLCA. The LCA and SLCA approaches support the policy process and decision making to prevent and provide scenarios for improvement of adverse environmental impacts of the production process.

\section{Literature Review}

\subsection{Circluar Economy}

Circular economy has aim to conserve natural resource by substituting product with service and designing thisng to be used again before the materials are recovered.The Circular economy combines various concepts of industrial ecology, cradle to cradle theorem, and blue economy [11].CE is based on: First, protect environmental capital, and develop it, and the balance of renewable resource flow. Second, optimize resource extration, ant the third is to minimize negative externalities eliminate toxic subtance [11].Circular Economy relies heavily on the 3R principle: Reduce, Reuse and Recycle [12]. The purpose of an LCA assessment is to measure the potential environmental impacts of a product system throughout its life cycle and to obtain appropriate conclusions and recommendations to reduce environmental impacts [13]. The combination of the use of LCA and CE allows product development by considering environmental impacts and ensuring a good environmental balance of the product circle design. In addition, an SLCA assessment is also needed to find out how the social impact of production activities. The LCA and SLCA approaches allow support for policy processes and decision making to prevent and provide improvement scenarios regarding adverse environmental impacts of the production process [14]. 


\subsection{Life Cycle Assessment}

According to ISO 14040 [15], Life Cycle Assessment (LCA) is a method used to gather and evaluate input, output, and potential environmental impacts from a product system during its life cycle. Life Cycle Assessment (LCA) method is used to identify the amount of energy, expense, and environmental impacts caused by the life cycle stages of a product, starting from the gathering of raw material until when the product is used up by a consumer [16]. According to ISO 14040 (2006) there are four stages of Life Cycle Assessment: goal and scope, Life Cycle Inventory (LCI), Life Cycle Impact Assessment (LCIA), and interpretation. The determination of purpose and scope will determine the result of the study and the decision to be made [16]. The purpose of using LCA method in this study is to assess the life cycle of a product, so that the researcher may discover the environmental impact caused by the production process of chair [17].

Life Cycle Inventory (LCI) is the stage of data gathering and calculation procedure of the input and output required in a product system [17]. Input and output data depends on the predetermined purpose and scope. The input and output data are used for the calculation of a product lifetime and the energy used in production process that may impact the environment [18]. Life Cycle Impact Assessment (LCIA) is the stage intended for understanding and evaluating the significance of a potential environmental impact of the life cycle of a product. There are five assessment stages in LCIA: classification, characterization, normalization, weighting, and single score [15].

\subsection{Social Life Cycle Assessment}

Social Life Cycle Assessment (S-LCA) is a tool for evaluating social impact. Social impact is related to the socio-economic impacts of a product, process, activity, and facility [19]. S- LCA is a social impact assessment, and it assesses both real and potential impact with the purpose of assessing social and socio-economic impacts of a product through its life cycle [20]. The main purpose of doing a S-LCA assessment is to improve the social condition and socioeconomic performance of a product through its life cycle for every stakeholder. S-LCA is used to identify social impact that arises from production process for related stakeholders.

S-LCI is used to assess the relation between a company and its stakeholders. Below are the stages in S-LCI:

- Identifying stakeholder

According to Drayer (2010) [21], there are six types of stakeholder that are affected by the social impacts of a company activity: worker, local community, society, customer, and supply chain actors.

- Identifying social impacts indicator (impact subcategories)

- Data gathering

During S-LCIA stage, an assessment analysis is done by processing the data that are gathered from S-LCI. The social impact on SLCA may impact stakeholder in a positive or negative way [10].

Interpretation in social life cycle assessment is a systematic stage with the purpose of identifying, measuring, checking, and evaluating information from SLCI and SLCIA analysis result, which are adjusted to the predetermined purpose and scope. 


\section{Method}

\subsection{Life Cycle Assessment}

LCA study is started by determining the goals and scope. The scope of LCA will evaluate the product in the "gate to gate" scope, that is only in the scope of production phase in accordance with the LCA scheme.

The second step of the LCA is Life Cycle Inventory. In this study, input is the raw materials that needed to produce a chair. However, the output of this study is the waste which come from the production process. The data needed is obtained from direct observation and interviews. The collected data will be used as input for SimaPro software.

In the next step, Life Cycle Impact Assessment will be calculated with stages including characterization, normalization, weighting, and single score. Life Cycle Impact Assessment calculations is done by using SimaPro eco-indicator 99 software.

At this stage, an interpretation of the results of the LCI and LCIA is carried out to reach conclusions and recommendations that are consistent with the goal and scope definition. Interpretation of the life cycle assessment is carried out by identifying, measuring, checking and evaluating information from the results of the LCI and LCIA analysis.

\subsection{Social Life Cycle Assessment}

The purposes of the S-LCA studies are to know the social impact caused by the production process and X activity to stakeholders. At the S-LCI stage which uses to assess the relation between company and their stakeholders. In this study, the chosen stakeholder are worker and local community. After the stakeholder is chosen, there will be the identification to indicators that is going to be use. The indicators are obtained from UNEP/SETAC 2009 [22], which have been used in previous studies. The indicators used can be seen in table 1 and table 2 . The next procedure is validation to indicators. The validation is carried out by distributing questionnaires to experts consisting of the Head of the Social and General Affairs of Sragen Regency, the Head of Industry of the Industrial Service of Sragen Regency, and the owner of the X company. Indicators validation aim to find out what the writer uses on the S-LCA in the furniture industry. The questioner method is using Likert scale of 1 to 5, with (1) equals to very inappropriate, (2) equals inappropriate, (3) equals to neutral, (4) equals to appropriate, and (5) equals to very appropriate. Furthermore, data collection is done by distributing questionnaires related to indicators of selected stakeholders. The questionnaire is distributed to 5 workers, and 5 local communities by filling out the questionnaire with a variable score of 1 if appropriate and -1 if not appropriate. S-LCIA is the step of assessing data that have been gathered in S-LCI. The results of the assessment will be made into assessment for the criteria and indicator assessed by the stakeholders. Below is the formula used to calculate the social impact [19]:

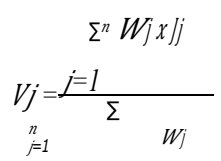

Explanation:

$\mathrm{SVj}=$ Variable $\mathrm{j}$ Score

$\mathrm{Wj}=$ Indicator Quantitiy on Variable $\mathrm{j} \mathrm{Jj} \quad=$ Indicator Score of Variable $\mathrm{j}$

$\mathrm{N}=$ Total Indicator of Variable $\mathrm{j}$ 
Table 1. Variabel S-LCA of Worker

\begin{tabular}{|c|c|c|}
\hline Stakeholder & Variable & Indicator \\
\hline & & Workers are free to hold collective laboring \\
\hline & reedom of joining & Workers are free to join a labor union they choose \\
\hline & $\begin{array}{l}\text { the labor union } \\
(\mathrm{P} 1)\end{array}$ & $\begin{array}{l}\text { Workers have the right to solve problems in a neutral, } \\
\text { binding and independent manner }\end{array}$ \\
\hline & & No underage worker (Under 18th) \\
\hline & Worker's ages & $\begin{array}{l}\text { No underage workers doing hazardous work (ILO } \\
\text { C138 dan C182) }\end{array}$ \\
\hline & $(\mathrm{P} 2)$ & Worker's age records are kept in written files \\
\hline & & $\begin{array}{l}\text { Minimum worker's wage according to government } \\
\text { rule }\end{array}$ \\
\hline & & $\begin{array}{c}\text { Workers (with lowest wage) assume their wages meet } \\
\text { their meet }\end{array}$ \\
\hline & $\begin{array}{l}\text { Minimum wage } \\
\text { (P3) }\end{array}$ & $\begin{array}{c}\text { Tidak terdapat potongan gaji yang mencurigakan No } \\
\text { suspicious wage cut }\end{array}$ \\
\hline & & Payments are made regularly and archived \\
\hline & & Working hours and overtime hours contract (If exists) \\
\hline & & $\begin{array}{c}\text { Overtime hours rules (Ex: overtime hours duration, } \\
\text { breaktime rules) }\end{array}$ \\
\hline & & $\begin{array}{c}\text { Jam kerja } 8 \text { jam setiap hari } 8 \text { hours of working time } \\
\text { daily }\end{array}$ \\
\hline & Work hours (P4) & $\begin{array}{c}\text { Clear information of working hours and overtime } \\
\text { hours }\end{array}$ \\
\hline \multirow{13}{*}{ Worker } & \multirow{2}{*}{$\begin{array}{l}\text { Fair opportunities } \\
\text { and free from } \\
\text { discrimination } \\
\text { (P5) }\end{array}$} & Worker's rights rules available \\
\hline & & $\begin{array}{l}\text { Discrimination among workers (gender, age, wage, } \\
\text { positiion, etc) }\end{array}$ \\
\hline & \multirow{3}{*}{$\begin{array}{l}\text { Working pressure } \\
\text { (P6) }\end{array}$} & $\begin{array}{c}\text { Workers voluntarily agree to terms of work (Wages, } \\
\text { working hours, leave) }\end{array}$ \\
\hline & & No coercion in work \\
\hline & & $\begin{array}{c}\text { Workers are free to end their work according to the } \\
\text { initial employment contract }\end{array}$ \\
\hline & \multirow{6}{*}{$\begin{array}{l}\text { Health and safety } \\
\text { (P7) }\end{array}$} & There has never been a fatal accident at work \\
\hline & & $\begin{array}{l}\text { There is a written policy or regulation on health and } \\
\text { safety }\end{array}$ \\
\hline & & There are steps in preventing accidents \\
\hline & & There are vacuum cleaners in the production area \\
\hline & & $\begin{array}{c}\text { The company violates occupational safety and health } \\
\text { regulations }\end{array}$ \\
\hline & & $\begin{array}{l}\text { There is training on prevention and control of risks in } \\
\text { dealing with accidents }\end{array}$ \\
\hline & \multirow[b]{2}{*}{$\begin{array}{l}\text { Social Insurance } \\
\text { (P8) }\end{array}$} & $\begin{array}{c}\text { There are no breaches of obligations to workers } \\
\text { regarding social security }\end{array}$ \\
\hline & & $\begin{array}{l}\text { Worker's insurance at work (Ex: Employment } \\
\text { Insurance) }\end{array}$ \\
\hline
\end{tabular}


Table 2. Variabel S-LCA of Local Community

\begin{tabular}{|c|c|c|}
\hline Stakeholder & Variable & Indicator \\
\hline \multirow{9}{*}{$\begin{array}{l}\text { Local } \\
\text { Community }\end{array}$} & $\begin{array}{l}\text { Access to material } \\
\text { resources }(\mathrm{L} 1)\end{array}$ & $\begin{array}{c}\text { The company builds access infrastructure together with } \\
\text { the local community } \\
\begin{array}{c}\text { No conflicts that are related to access infrastructure with } \\
\text { the local } \\
\text { community }\end{array} \\
\end{array}$ \\
\hline & $\begin{array}{l}\text { Cultural heritage } \\
\text { (L2)e }\end{array}$ & $\begin{array}{c}\text { The company activities does not interrupt the culture } \\
\text { available }\end{array}$ \\
\hline & \multirow{3}{*}{$\begin{array}{l}\text { Healthy and safe } \\
\text { living condition } \\
\text { (L3) }\end{array}$} & The reduction of dangerous substances \\
\hline & & No threat from the company \\
\hline & & $\begin{array}{c}\text { No hazard exposure and diseases resulting from } \\
\text { production activities }\end{array}$ \\
\hline & \multirow{2}{*}{$\begin{array}{l}\text { community } \\
\text { engagement (L4) }\end{array}$} & $\begin{array}{c}\text { The company builds good communication and } \\
\text { relationships between the company and the local } \\
\text { community }\end{array}$ \\
\hline & & Written policies for community involvement \\
\hline & \multirow{2}{*}{$\begin{array}{l}\text { Local workers } \\
\qquad \text { (L5) }\end{array}$} & Local workers percentage \\
\hline & & Supplier percentage/local supplier \\
\hline
\end{tabular}

\section{Results and discussion}

\subsection{Life Cycle Assessment}

Single score stage is the last stage of LCA. The environmental impact potential produced by each activity unit can be identified from the single score result. Finishing process has the highest single score result of $65.20296 \mathrm{mPt}$, followed by assembly process with $22.3507 \mathrm{mPt}$; construction process with $6.215397 \mathrm{mPt}$; cutting process with $1.888599 \mathrm{mPt}$. The result of single score can be viewed based on midpoint and endpoint impact categories. The results of endpoint impact are human healthy, ecosystem quality, and resources. Single score results based on end point impact categories can be seen on figure 1. The single score result of human health impact amounts to $41.06254 \mathrm{mPt}$; ecosystem quality $2.127813 \mathrm{mPt}$; resources $52.46729 \mathrm{mPt}$. The total environmental impact of the production process of a chair amounts to $95.65765 \mathrm{mPt}$.

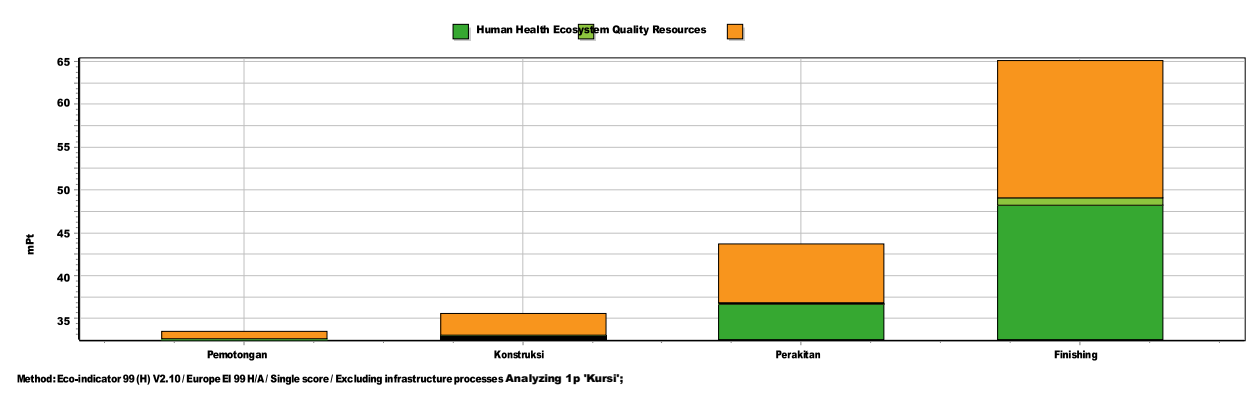

Fig. 1. LCA Endpoint Result

Based on the result of data processing and data analysis of this study, the largest contributor to environmental impact is the use of acrylic varnish. Paint business actors suggest replacing acrylic varnish with woodstain water based, which is similar to acrylic 
vanish in that it also acts as clear paint. Table 3 is the comparison between the environmental impacts of both materials.

Tabel 3. LCA Result Comparison

\begin{tabular}{|c|c|c|}
\hline Material & $\begin{array}{c}\text { Finishing Impact Point } \\
\text { (mPt) }\end{array}$ & $\begin{array}{c}\text { Total Impact Point } \\
\text { (mPt) }\end{array}$ \\
\hline Acrylic Varnish & 65,20296 & 95,65765 \\
\hline Woodstain Water Based & 41,40189 & 71,85658 \\
\hline
\end{tabular}

Substitution acrylic varnish with woodstain water based aims to lead to a circular economy by reducing adverse impacts on the environment. It can be seen from table 3 that the replacement of acrylic varnish with woodstain water based reduces the environmental impact score by $24.8 \%$. Acrylic varnish, a finishing material that gives a clear coat and is applied on the last layer, may turn yellow overtime. This change of color may obscure the original color of the wood. Meanwhile, woodstain water based is a material that very closely resembles paint that are designed to give color to wood, and it can permeate into the wood surface, hence showing the wood fibers. According to finishing experts, woodstain that uses water solvent has the lowest fire risk. The material is also environmental friendly and non- toxic. Woodstain is made of pigment mixture, solvent, and a bit of binder and additive.

\subsection{Social Life Cycle Assessment}

\section{Worker Stakeholder}

Based on the figure 2, worker variables on P4, P6, and P7 have the lowest score. P4 shows work hour variable, which is related to the total amount of work hour, overtime hour, and detailed information regarding work hour and overtime hour. The low score is caused bythe fact that there is no contract, rule, or clear information regarding work hour and overtime hour. Based on an interview with the workers, it is known that there is no clear information and rules regarding overtime hour in $\mathrm{X}$, which is proven by the fact that the average worker overtime duration is 45 hour per day. Meanwhile, it is clearly stated in Article 78 Section (1) Act Number 13 Year 2003 and Article 3 Kepmenakertrans No. 102/MEN/VI/2004 about overtime hour and overtime wage that "the maximum overtime hour is 3 hours in a day and 14 hours in a week". Moreover, the workers also complained about the lack of clear information of overtime hour wage. According to the Ministry of Manpower Regulation No. KEPMEN No. 102 Year 2004 Article $11 \mathrm{a}$, if an overtime is done on weekdays, the worker has to be paid 1.5 times the usual hourly wage and for each hour after, he has to be paid twice the usual hourly wage. According to a study conducted by Safiuddin (2001) there is a significant connection between a suitable wage, which takes into account the work hour or overtime hour and work facility, and the workers' discipline rate [23].

P6 shows work pressure variable, which is related to the absence of pressure in working and workers's approval of working requirements. In this variable, workers state that they are sometimes pressured into working. As an example, when there is a high consumer demand, workers are forced to work faster. High working pressure makes it difficult for the workers to channel their energy efficiently because they have to exert bigger effort. This influences the workers' performance negatively.

P7 shows health and safety variable. The variable explains work accidents that have occurred in the past, healthy and safety policy, and whether X holds accident prevention training for the workers. In $\mathrm{X}$, there are no rules regarding health and safety, standard procedure for 
preventing accidents, or even accident prevention training. According to Constitutional Act Number 1 Year 1970 Article 14, one of the management responsibilities is to put up work safety posters on strategic location so that the workers can easily see those posters. To increase social impacts on the workers, it is recommended that $\mathrm{X}$ set maximum overtime hours to three hours per day. Moreover, overtime pay must be given according to the rules. To decrease the number of complain regarding working pressure, $\mathrm{X}$ also has to pay more attention to the workers, which can be done by holding a routine gathering event, where workers can gather together to expresstheir criticism and suggestion. X needs to be more knowledgeable and gives more information regarding job safety analysis and steps in preventing accidents by using materials that are not easily wet, and holding a safety talk with the workers.

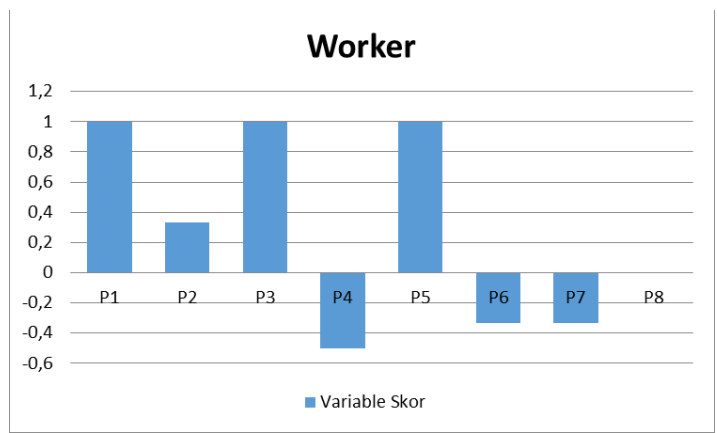

Fig 2. The SLCA Result of Worker Stakeholder

\section{Local Community Stakeholder}

Based on the figure 3, L4 variable or community engagement scores the lowest. Community engagement variable is related to good communication between the company and the local community. The low score is caused by the lack of good communication between the company and the local community. Besides that, there are also no talks regarding company policy regarding the local community participation. Based on the interview with the leader of the local community association, $\mathrm{X}$ does not participate in any local community activities. The purpose of a business is not only to gain profit, but also to maintain the continuity and social responsibility of the company. Currently, social responsibility such as pollution controlling, eradicating practices of discrimination, and energy saving, is an important purpose

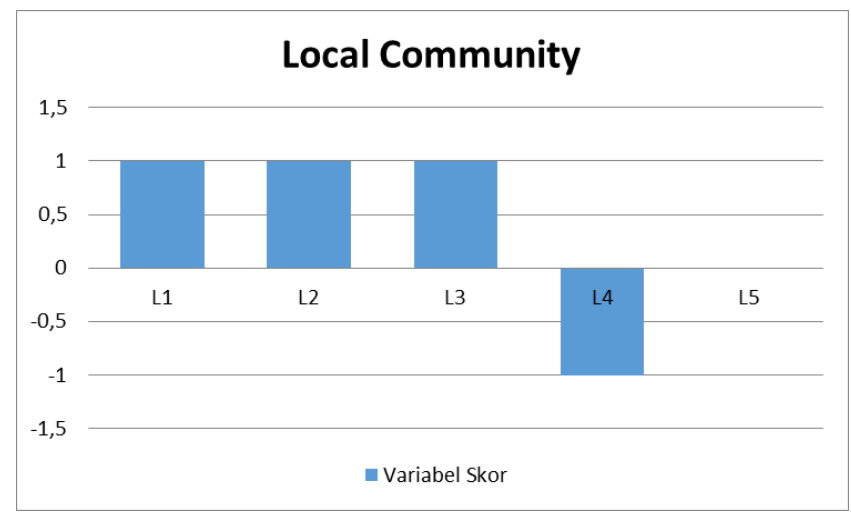

Fig 3. SLCA Result of Local Community Stakeholder 
It is recommended to increase social impact to the local community by building public infrastructure, such as by installing streetlights near $\mathrm{X}$ building, or by giving public infrastructure aid to the local community, giving out aids to the local community during Eid alFitr, or helping the local community in celebrating the Independence Day, and communicate with the local community to stay aware of every progress that happens in the community.

\section{Conclusion}

Based on the result of LCA calculation by SimaPro 9 software, the writer obtains an environmental impact score of $95.65765 \mathrm{mPt}$. Where the finishing process has the highest single score result of $65.20296 \mathrm{mPt}$, followed by Assembly process with $22.3507 \mathrm{mPt}$; Construction process with $6.215397 \mathrm{mPt}$; Cutting process with $1.888599 \mathrm{mPt}$. The largest contributor to environmental impact is the use of acrylic varnish. Substitution acrylic varnish with woodstainwater based aims to lead to a circular economy by reducing adverseimpacts on the environment. The replacement of acrylic varnish with woodstain water based reduces the environmental impact score by $24.8 \%$.

Based on S-LCA calculation result, social impact score on the workers amounts to $27.0834 \%$ which is categorized as poor. Worker variable with low scores are work hours, working pressure, and work health and safety. Meanwhile, the social impact score on local community stakeholder amounts to $40 \%$ which is also categorized as poor, with community engagement as the lowest scoring local community variable.

\section{References}

1. Tonelli, M., \& Cristoni, N., Strategic Management and the Circular Economy. In Strategic Management and the Circular Economy (2018)

2. Iacovidou, E., Millward-Hopkins, J., Busch, J., Purnell, P., Velis, C. A., Hahladakis, \& Brown, A. A pathway to circular economy: Developing a conceptual framework for complex value assessment of resources recovered from waste. Journal of Cleaner Production, 168, 1279-1288 (2017)

3. Rinawati, D. I., Sriyanto, Sari, D. P., \& Prayodha, A. C. Eco-efficiency Analysis of Furniture Product Using Life Cycle Assessment. E3S Web of Conferences, 31 (2018)

4. Purwanto, D. Pembuatan Balok Dan Papan Dari Limbah Industri Kayu. Indonesian Journal of Industrial Research, 5, 1 (2011)

5. Daian, G., \& Ozarska, B. Wood waste management practices and strategies to increase sustainability standards in the Australian wooden furniture manufacturing sector. Journal of Cleaner Production, 17(2009)

6. Çinar, H. Eco-design and furniture: Environmental impacts of wood-based panels, surface and edge finishes. Forest Products Journal, 55 11(2005)

7. Kamps, G. R. L. Environmental analysis of wooden furniture. Product Innovation and EcoEfficiency (1998)

8. Adhikari, S., \& Ozarska, B. Minimizing environmental impacts of timber products through the production process "From Sawmill to Final Products." Environmental Systems Research, 7, 1 (2018)

9. Yang, M., \& Rosentrater, K. A. Environmental effects and economic analysis of adhesives: A review of life cycle assessment (LCA) and techno-economic analysis (TEA). American Society of Agricultural and Biological Engineers Annual International Meeting 5 (2015)

10. Dunmade, I., Udo, M., Akintayo, T., Oyedepo, S., \& Okokpujie, I. P. Lifecycle Impact Assessment of an Engineering Project Management Process - A SLCA Approach. IOP Conference Series: Materials Science and Engineering, 413(1). Sharaai, A. H., 
Muhammad, K. I., \& Wah, Y. G. (2019). Social impact evaluation of tea production using social life cycle assessment (s-lca) method in cameron highlands, pahang, Malaysia. Planning Malaysia, 17, 2 (2018)

11. Tóth Szita, K. The application of life cycle assessment in circular economy. Hungarian Agricultural Engineering, 31 (2017)

12. Ranta, V., Aarikka-Stenroos, L., \& Mäkinen, S. J. Creating value in the circular economy: A structured multiple-case analysis of business models. Journal of cleaner production, 201 (2018)

13. Dieterle, M., Schäfer, P., \& Viere, T. Life cycle gaps: interpreting LCA results with a circular economy mindset. Procedia CIRP, 69 764-768 (2018)

14. Neugebauer, S., Traverso, M., Blengini, G. A., Mathieux, F., \& Peiter, C. C. Social Life Cycle Assessment of Niobium Mining in Brazil in a Circular Economy context. Social $L C A, 194$ (2018)

15. ISO. 14040: Environmental management-life cycle assessment-Principles and framework. International Organization for Standardization. (2006)

16. Harjanto, T. R., Fahrurrozi, M., \& Bendiyasa, I. M. Life Cycle Assessment Pabrik Semen PT Holcim Indonesia Tbk. Pabrik Cilacap: Komparasi antara Bahan Bakar Batubara dengan Biomassa. 6(2), 51-58. Hauschild, M., Jeswiet, J., \& Alting, L. (2005). From life cycle assessment to sustainable production: Status and perspectives. CIRP Annals Manufacturing Technology, 54, 2 1-21 (2014)

17. Khasreen, M. M., Banfill, P. F. G., \& Menzies, G. F. Life-cycle assessment and the environmental impact of buildings: A review. Sustainability, 1, 3 674-701 (2009)

18. Steinbach, V., \& Wellmer, F. W. (2010). Consumption and use of non-renewable mineral and energy raw materials from an economic geology point of view. Sustainability, 2(5), $1408-1430$.

19. Dunmade, I. Social Lifecycle Assessment of Sachet Water: A Case Study on a Nigerian Facility's Impacts on Workers and the Local Community. 5, 6 31-45 (2016)

20. Petti, L., Serreli, M., \& Di Cesare, S. Systematic literature review in social life cycle assessment. International Journal of Life Cycle Assessment, 23, 3 422-431 (2018)

21. Dreyer, L. C., Hauschild, M. Z., \& Schierbeck, J. (2010). Characterisation of social impacts in LCA. Part 2: Implementation in six company case studies. International Journal of Life Cycle Assessment, 15(4), 385-402.

22. Benoît, C., Norris, G. A., Valdivia, S., Ciroth, A., Moberg, A., \& Beck, T. The guidelines for social life cycle assessment of products: just in time. The international journal of life cycle assessment, 15, 2 156-163 (2010)

23. Safiuddin, M. Global ozone depletion: causes, effects and preventive measures. Borneo Science, 73-89. (2001) 